\title{
DESAIN ULANG INSTALASI PERPIPAAN PADA MESJID NOOR BANJARMASIN
}

\author{
Muhammad Firman, Muhammad Irfansyah, Budi Hartadi, Heri Irawan, dan \\ Mujiburrahman \\ Fakultas Teknik, Universitas Islam Kalimantan MAB \\ Email :firmanuniska99@gmail.com
}

\begin{abstract}
Service aims to assist the pilgrims so that not too long queue when the purification ritual, so that problems that had been faced by the mosque Noor about the uneven distribution of water during ablution can be resolved by means of installing a piping system so that the water supply everyone on water tank or reservoir can be filled and evenly all these divisions reservoir, so that when the full-full of pilgrims could be served all and not so many pilgrims who cannot attend the prayer in congregation. The main target of this activity is the management of the mosque and the mosque, because they always get complaints and direct censure of pilgrims due to uneven supply of water during ablution, so they need to know how to properly install piping system.

The method used to achieve the objectives that have been implemented are: to perform the installation of the channel that goes into reservoirs and channels out of the reservoir so that the distribution of water for ablution can be evenly and flowed perfectly.

From the results of this activity all the reservoir can get a direct supply from the pump or other sources, the supply of water for ablution can run smoothly is that during these 14 taps of 43 taps for ablution place of men who do not get water supply now is $100 \%$ get water or completely get water supply, in the place of ablution women there are six taps that do not get water from 17 taps installed there now entirely get water supply, as well as the bathroom which amounted to 14 taps, as well as urinal male 8 taps obtain equitable water supply. Djuhur prayers and implementation are now only approximately 1 shap or 40 worshipers who pray it too late due to the late arrival of pilgrims.
\end{abstract}

Keywords: tank, faucet, ablution

\section{PENDAHULUAN}

Mesjid Noor adalah salah satu masjid yang terletak di lingkungan pusat perbelanjaan di Kotamadya Banjarmasin, diantaranya Pasar Cempaka, Pasar Sudimampir dan Pasar Harum Manis. Ketiga pasar tersebut merupakan tempat jual beli yang paling rami dan terlengkap di Banjarmasin, jamaah Masjid Noor lebih kurang 680 jamaah yang melakukan sholat terutama sholat djuhur dan sholat Ashar. Dimesjid Noor terdapat 17 shap yang tiap shapnya menampung sekitar 40 jamaah.

Pada sholat djuhur ada lebih kurang 2 sampai 3 shap jamaah yang terlambat sholat berjamaah disebabkan jamaah selalu mengantri cukup lama untuk berwudhu karena ada beberapa 
keran yang tidak mengeluarkan air hal tersebut disebabkan oleh bak penampungan atau tandon yang ada tidak terisi penuh sehingga tekanan air yang ada kecil (http://hargareview.com/tips-memilihtandon-air-yang-baik).

Banyaknya keran untuk berwudhu ditempat laki-laki 43 keran dan ditempat perempuan 17 keran. Sedangkan untuk kamar mandi ada 14 keran ditambah 8 keran ditempat buang air kecil laki-laki. Jumlah tandon atau bak penampungan ada 10 buah dengan kapasitas tiap tandon 1200 Liter.

Tujuan dari pelaksanaan ini adalah membantu masyarakat/jamaah:

1. Supaya tidak terlalau lama mengantri saat berwudhu.

2. Supaya masalah yang selama ini dihadapi oleh masjid Noor mengenai tidak meratanya pembagian air saat wudhu dapat teratasi.

Manfaat yang ingin dicapai dalam kegiatan ini adalah untuk menghasilkan suplai air kesemua bak penampungan air atau tendon bisa terisi penuh dan merata pembagiannya kesemua tendon, sehingga saat penuhpenuhnya jamaah bisa terlayani semua dan tidak begitu banyak lagi jamaah yang tidak dapat mengikuti sholat berjamaah.

\section{KHALAYAK SASARAN}

Sasaran utama kegiatan ini adalah pengurus masjid dan kaum masjid, karena mereka yang selalu mendapatkan keluhan maupun cercaan langsung dari jamaah akibat tidak meratanya suplai air saat wudhu, jadi mereka perlu tau bagaimana menginstalasi sistem perpipaan yang benar.

\section{METODE}

Metode yang akan digunakan untuk mencapai tujuan yang telah dicanangkan yaitu: dengan melakukan penginstalasian ulang salauran yang masuk ketandon dan salauran yang keluar dari tendon sehingga distribusi air untyuk wudhu dapat merata dan teralirkan dengan sempurna. Di akhir kegiatan di harapkan suplai air untuk wudhu dapat merata sehinga jamaah yang yang terlambat untuk ikut sholat berjaamaah tidak ada lagi atau berkurang. Serta juga pengurus dan kaum masjid dapat menginstalasi sendiri jika ada penambahan keran dan tandon air. 


\section{HASIL DAN PEMBAHASAN}

Kegiatan awal yang dilakukan oleh Tim Pengabdian Pada Masyarakat adalah berkoordinasi dengan pengurus Masjid Noor Banjarmasin untuk melakukan survey instalasi perpipaan di masjid tersebut dan menentukan waktu pelaksaaan yang tepat sehingga tidak menganggu aktifitas jamaah di masjid tersebut. Pada sholat djuhur ada lebih kurang 2 sampai 3 shap jamaah yang terlambat sholat berjamaah disebabkan jamaah selalu mengantri cukup lama untuk berwudhu karena ada beberapa keran yang tidak mengeluarkan air hal tersebut disebabkan oleh bak penampungan atau tandon yang ada tidak terisi penuh sehingga tekanan air yang keluar kecil dan ada sebagian keran yang tidak mendapatkan suplai air.

Pelaksanaan penginstalasian dilaksanakan pada bulan Desember 2016 selama 2 hari. Dan kegiatan berjalan lancer dengan mendapatkan dukungan dari pengurus masjid untuk kelancaran kegiatan dengan meminjamkan peralatan yang kami perlukan.

\section{FOTO KEGIATAN}
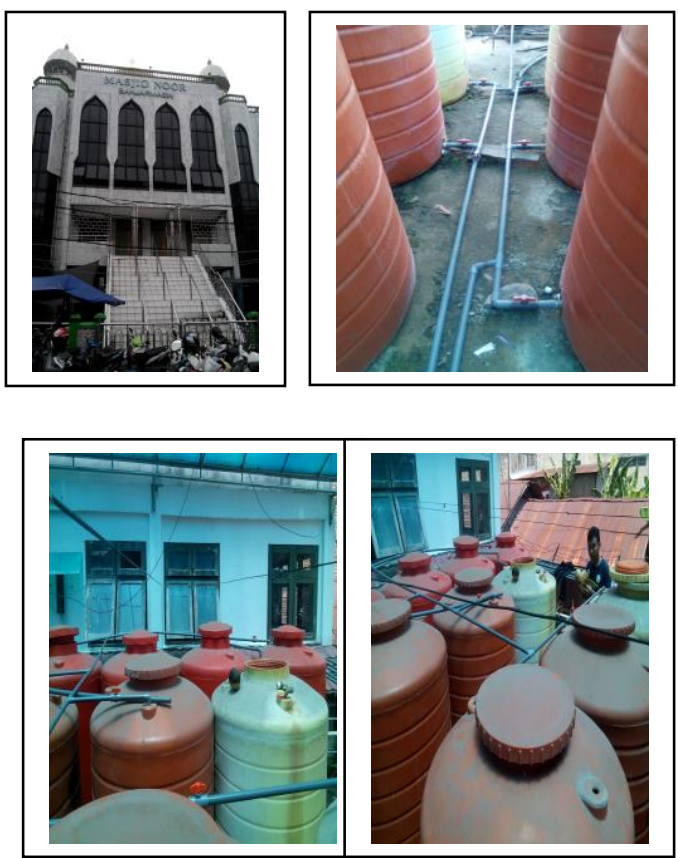

Selama proses penginstalasian dukungan dan antusias dari pengurus masjid sangat baik sekali, karena hal tersebut sangat mereka harapkan sekali untuk mengatasi supaya suplai air untuk wudhu dapat lancar. Perbaikan penginstalasian pada bagian pemasukan air dari pompa ke tandon air yang hanya menggunakan 3 tandon untuk mensuplai ke 7 tandon yang lain dari 10 tandon yang ada. Setelah kami lakukan desain ulang dengan merubah instalasinya dari yang 3 tandon untuk meyuplai air ke 7 tandon yang lain dengan menjadikan semua tandon dapat mendapatkan suplai langsung dari pompa atau sumber yang lain.

Penginstalasian pipa suplai air untuk wudhu dapat berjalan lancar yaitu 
yang selama ini 14 keran dari 43 keran untuk wudhu ditempat laki-laki yang tidah mendapatkan suplai air sekarang sudah $100 \%$ mendapatkan air atau seluruhnya mendapatkan suplai air. Pada tempat wudhu perempuan ada 6 keran yang tidak mendapatkan air dari 17 keran yang terpasang disana sekarang sudah seluruhnya mendapatkan suplai air, begitu juga dengan kamar mandi yang berjumlah 14 keran, serta tempat buang air kecil lakilaki 8 keran mendapatkan suplai air yang merata. Pada pelaksanaan sholat djuhur sekarang hanya ada kurang lebih 1 shap atau 40 orang jamaah yang terlambat sholat berjamaah itu juga disebabkan karena jamaah tersebut datangnya terlambat

\section{KESIMPULAN}

Dari hasil penginstalasian dapat disimpulkan bahwa instalasi untuk kran air pada fasilitas umum sangat diperlukan untuk efesiensi penggunaan air sehingga pengeluaran biaya lebih efesien.

\section{DAFTAR PUSTAKA}

M. Orianto, W.A Pratikto. 1984. Mekanika Fluida I. Surabaya.

Theresia Pynkyawati \& Shirley

Wahadamaputera. 2015. Utilitas

Bangunan Modul Plumbing.

Jakarta. Penerbit Griya Kreasi.

Journal:

Sudiyo utomo, Tri. M. W. Sir \& Albert

Sonbay. 2012. "Desain Saringan

Pasir Lambat Pada Instalasi

Pengolahan Air Bersih (Ipab)

Kolhua Kota Kupang". Jurnal

Teknik Sipil Vol 1. No. 4

September 2012.

Rujukan Elektronik:

http://www.merdeka.com/sehat/7-caramudah-menghemat-air.html

https://id.wikipedia.org/wiki/Wudu\#Sun nah_wudu

http://hargareview.com/tips-memilihtandon-air-yang-baik

http://dokumen.tips/documents/sistemperpipaan-55c2a65e0a24b.html 